\title{
Strategy and operation in dynamic interaction
}

\author{
P.Haho \\ TAI Research Centre, Helsinki University of Technology \\ P.O. Box 9555, 02015 HUT, Finland, tel. + 358-9-451 5032, fax \\ $+358-9-451$ 3665, e-mail: paivi.haho hut.fi
}

\begin{abstract}
This paper describes the empirical experience and results of the case companies in which we have applied change methods based on evolution management. The knowledge creation and accumulation for interaction between the strategy and operational processes have been modeled and the facts that affect the interactions have been studied. The final goal has been to uncover the results which lead to strategic competitiveness.
\end{abstract}

\section{Keywords}

strategy, operations, empowerment, knowledge creation and accumulation

Title of book. Name of editors (Eds.)

(C) 1997 IFIP. Published by Chapman \& Hall 


\section{INTRODUCTION}

The future success of industrial companies is founded on the capability to create new business strategies and operation processes fast and effectively. Strategic and operational decision making need to account for each other. The better the interaction, the better are the results in business or process innovations.

Strategy is more than just competitive strategy: strategy should be operative and operative strategic to ensure competitiveness. Poor and slow operative processes could be barriers to accomplishing the desired strategy. In practice these barriers can be the inertia of old working habits and the lack of interaction between functions and organizations. Behind these hindrances lie multiple factors which management should be aware of, and consider simultaneously to increase the potential for the successful fulfillment of strategy. If people are not committed to it or their visions are not in line with the company's strategy, its realization can be delayed or even fail.

On the other hand, new ideas and views of personnel are an integral part of the strategy building process. These new ideas arise from the interaction between the cross-functional and cross-hierarchical relations of top management, employees and experts. The driving force behind enterprise development is in innovation. Innovations stem from the interaction of creative individuals at all levels of the organization (e.g. Burgelman 1983, Moss Kanter 1983, van de Ven 1986, Smeds 1996).

Both bottom-up and top-down management are crucial to realizing the goals in innovation and knowledge accumulation in an organization. "Creating new knowledge is not simply a matter of learning from others or acquiring knowledge from outside. Knowing has to be built up on its own, frequently requiring intensive and laborious interaction among the members of the organization." (Nonaka and Takeuchi 1995). The organizational knowledge creation process is a spiral process starting at the individual level and moving up through an expanding interaction of departmental, divisional and organizational boundaries. The knowledge creation and accumulation process can start from an unexpected level of hierarchy or process function. The strategic advantages and better business processes emerge in an intensified interaction and experimentation of cross-functional and crosshierarchial movement, where tacit knowledge is converted into explicit knowledge and vice versa. The tacit knowledge connected to the new strategy or process structure materializes in the corporate culture and vision, and the explicit knowledge in the new technology, structure, rules and procedures (Nonaka and Takeuchi 1995). 


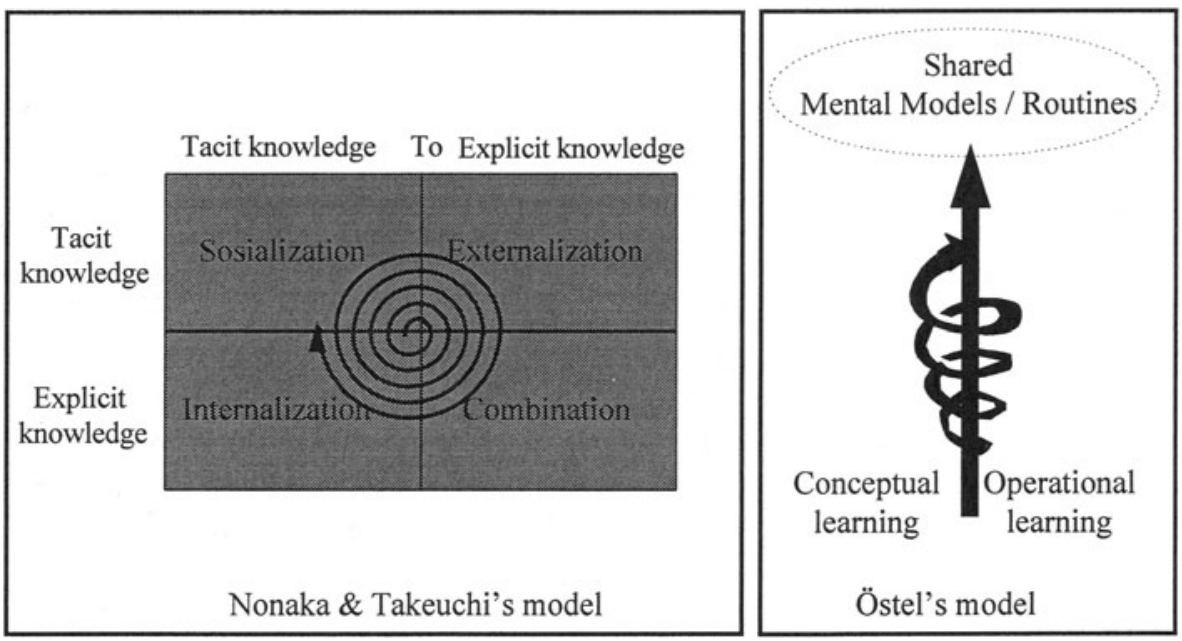

Figure 1. Nonaka's and Östel's models of knowledge creation in organizations . ${ }^{1}$

\section{METHODS}

I pursued my research inductively using four Finnish multinational firms as cases. The use of multiple cases allowed a replication logic whereby each case was used to test emerging theoretical insights. Data were collected primarily through semistructured individual questionnaires during the change project and follow-up studies were made along the project. The learning process model illustrated by Östel has been as a tool for data analysis.

\section{CASE EXAMPLES}

\subsection{Case 1: Building a new factory based on desired strategy}

\section{Background}

The case organization was a manufacturing unit in a large multinational company. It was functionally organized at that time, and advanced in product technology as well as in the use of management systems and automated production technology.

The roots of the project were in the rapid increase in demand for the products of the enterprise. Production in the old plant was organized according to product families, planned to inventory, and controlled with complex and inflexible

\footnotetext{
1 Östel's model illustrates the learning process, a slightly modified version of the model developed by Kim, 1993.
} 
computerized systems based on multilevel materials requirement planning. Purchasing, capacity planning and maintenance were centralized to staff functions. The situation at the old factory included long delivery times and unacceptable inventory levels and re-work. Quality and costs were not satisfactory either.

The new plant should resolve the problems through the implementation of highly automated, efficient and flexible production technology managed as an organizational and operational change. The objectives of the project were ambitious: the new plant should be competitive, efficient and human-oriented. It should operate according to customer order, with a reduced lead time and high productivity. Production should be coordinated in the pull mode. Visual control and simplicity were the aims of the new material flow. The organization should be as flat as possible, with enriched tasks and job rotation in manufacturing cells. The employees' technological know-how should be extensively increased.

\section{Interaction in strategy and operations}

Management had a strong strategic vision to serve customers well within desired markets, with old but modified products, establishing a new production technology in its own facilities which then allows change in operations based on proposed goals to serve customers. The visions, strategy and production and service tactics were formed as targets for the new plant project.

The strategy was clear, as were the goals for the project, but how to get there? From the start, emphasis was put on participation, teamwork, extensive training of employees and open communication within the project. The plans for the new factory were developed in a participative manner, with representation of all employees, as were the implementation plans. The principle of holistic knowledge guided the development work during the whole project, meaning management's and employees' shared understanding of the targets and proposed operations. The dynamic interaction between management and employees in the process simulations and planning meetings, teamwork meetings, excursions, benchmarking events, training sessions etc. was momentous. The spiral of the strategy and operations, concepts and practice was a learning pattern for realizing the best practices for customer service and future strategies. The extensive interaction during the two-year project led to a learning leap providing a durable base for more advanced service, technology and productivity development in future. The factory was years ahead of others in service capabilities (Fig. 2). 




Figure 2. Strategy and operations in collaborative and efficient interaction.

\section{Results}

The new plant was running at normal capacity just three months after the start-up. The lead time of production decreased from 20 to 3 days, with dramatically improved accuracy in deliveries. The inventory cycle time of parts and products increased by a factor of three. The defect rate of manufacturers parts had decreased from $1.7 \%$ to $0.5 \%$. The successful implementation of change had required a huge investment in personnel: during the planning and implementation, the hours spent in training rose from $1.5 \%$ to $7 \%$ of working time, after which it declined to the normal level. The project was a success from the point of view of customer service, competitiveness, productivity as well as work satisfaction. Management and personnel were also empowered to take on new challenges in other areas, for example with teamwork.

\subsection{Case 2: Re-engineering multinational operations based on actual strategy}

\section{Background}

The case organization was a large, traditional and slowly moving multinational company, which had operations on all continents. It was functionally organized, and its units were very independent of the management systems.

The change project was a business process re-engineering project: the definition and implementation of new business processes as well as IT systems world wide was the main goal of the project. The roots of the project were in the need for radical improvement and change in the service strategy and operations with a well- 
defined product and service offering. Customer service was unsatisfactory, organized according to complicated steps in the process for different market areas. The business processes were complex and unclear: overloaded resources had to overcome situations from day to day. The computer systems in sales and marketing was not up-to-date: they did not serve global business at all. The situation in the business chain added up to long delivery times and especially to an unsatisfactory level of delivery accuracy and slow response time to customers. The quality of customer documentation was not satisfactory either. The product range and its variation was a big question, as was the business segmentation.

New business processes, new product offerings with re-engineered products and new IT systems should resolve the problems through an efficient and flexible global business chain managed as an organizational and operational change. The customer service objectives of the project were ambitious: the process should reduce quotation time by $50 \%$, reach $100 \%$ delivery performance, achieve its best quotation and documentation level in industry and reduce order engineering time by $75 \%$. Profitability objectives were ambitious: reduce lead time and inventory and work in process value by $50 \%$, as well as number of designed items; double productivity with same number of personnel and reduce preparation time for management reporting by $90 \%$. The goals could be summarized as better and more focused service for customers, increased profitability and higher motivation of personnel.

\section{Interaction in strategy and operations}

Management had a vision to improve the business chain, with a new process structure and modern IT technology for modular products. The visions acted as targets for the business process re-engineering project.

The goals for the project were clear, but how to get there? From the start emphasis was placed on participation and teamwork especially in sales units. Information through official channels was functioned as normal. The plans for the business processes and IT investments were developed in a participative manner, with representation of small global groups of employees, as were the implementation plans. Steering meetings occurred with the support of the top management. But was the participation enough to cover the whole world, all cultures and different cultural manners? Was the support enough? Or was it virtual? Or was the principle of holistic knowledge in the project the same within each unit, at each level of the organization? Did the organization share the understanding of the targets and proposed plans in the same way? Was management aware of the momentum of all aspects of the project and their dependence on each other. Was the concept and practice as well as decision making according to plan? The interaction during the four-year project was quite intensive, but not sufficient enough for holistic knowledge to evolve between different units and staff members in connection with market and product strategy and service operations. The results of the project slowed down due to a lack of capability to change the product strategy and offerings in each business segment to 
support the development of customer service strategy and operations (Fig. 3). The biggest question remains: has the organization learned from the trial? What do concept and practice, strategy and operation mean? Are they never together, especially in large multidimensional development projects? How should we direct complex business process re-engineering projects to get the best results?



Figure 3. Strategy and operations in barrier loop.

\section{Results}

The new business processes were implemented with the same product range for each business segment as before, though with the new process channels and rules, with new global sales and customer documentation systems to achieve the customer service objectives. Change was going on, but not in all areas planned. The original goal to focus the product offering for each business and modularize the products failed. The implementation of the original time schedule was delayed due to a lack of knowledge to deal with the dependence of process implementation and product offering as well as with implementation methods to empower employee initiative in change.

The quality of the sales work and documentation have increased, lead time in the quotation process as well as in the whole sales-to-delivery process has decreased, as has reporting time, particularly in sales units. The goals concerning products have not really changed at all. To sum up: customer service have improved, though not sufficiently yet and the profitability objectives are yet to be fulfilled. Change is continuing in its implementation phase, and the final results have not yet been reported. 


\subsection{Summary of the case studies}

The most inevitable outcome according to the participants of the development projects was that participation either with game sessions or in other ways increased significantly the holistic view of the core process(es). Secondly, they felt that participation gave them a good view of the different subprocesses and their functions and interfaces. They reported that the game increased knowledge of the process and offered a new way of thinking as well as they learned to understand matters from new points of view. The identification of problems within the process and new ideas were also reported as a noteworthy outcomes of the participative sessions. The interaction between operations and strategic planning was also obvious and resulted in new insights in both directions.

If barriers exist between interfaces, as in case 2, they were caused through a lack of holistic knowledge and communication, especially at the beginning of the development assignments.

\section{DYNAMIC MODEL FOR STRATEGY AND OPERATIONS INTERACTION}

If the strategy building processes and operative processes are in intensive interaction, they both accumulate tacit and explicit knowledge for each other. Tacit knowledge of the organization is the competing power for the enterprise. Thus, the organization and business development models, which support socializing and then externalizing the existing tacit knowledge, are effective and innovative management tools. The following figure illustrates the dynamic model of strategy and operations interaction processes.

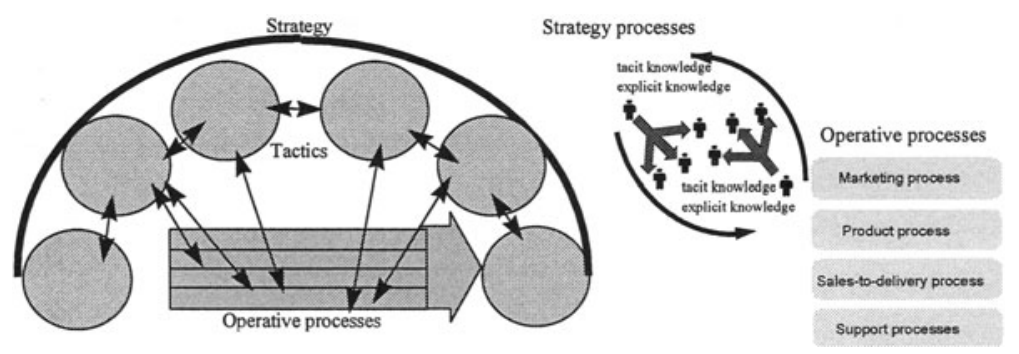

Figure 4. Knowledge accumulation in strategy and operations interaction. 
The results from these case studies indicate that the most important principles in the process and organization development in operations and strategy (cf. Smeds 1995,1996 and 1997) are the following aspects:

1. A holistic view of the processes: the comments of the participants after the simulation game indicate the importance of the holistic view as a prerequisite for development of the business processes and organization as well as process innovations. The systematic, simultaneous and visual connection between all individuals concerned results in shared understanding of the present situation and its change needs. After the holistic view is gained by the whole organization, the "fruits" can be picked later through small group work and teamwork.

2. Communication: careful communication and the informing of the whole organization is vital during the change process and also as a basic management principle overall. Participative methods like simulation games dealt with the priviation of the communication in organizations extremely well: during the second game the lack of communication was no longer a big issue after the shared experience in the first game.

3. Holistic knowledge: the dynamic accumulation of knowledge through knowledge creation, sharing and dissemination is the basis for a successful development approach. The participative methods bring together a company's explicit and tacit knowledge.

4. Interfaces: the development in organizations should focus on the process interfaces in operations as well as in strategy processes. The most striking results can be achieved by solving the problems in interfaces.

A high level of interaction between strategy and operation processes can shorten the lead-time of enterprise transformation by using dynamic knowledge creation, the middle-up-down approach and evolution management. Evolution management describes a strategy-based approach, where the magnitude of the transformation steps depends highly on the capability of the enterprise and its people over a given time period, and where the approach lies between reengineering and improvement.

We need creative, participative and systematic enterprise and process development methods (e.g. Haho 1997, Smeds 1997, Laakso 1997), in which the dynamic interaction of the strategic and operational approaches are taken into account. This helps us discover the change potential of strategy and business processes, to realize the changes needed and to manage them. 


\section{REFERENCES}

Brown, S. and Eisenhardt, K. (1998) Competing on the edge: Strategy as structured chaos, Boston, Harward Business School Press.

Burgelman, R.A. (1983) Corporate entrepreneurship and strategic management: insights from a process study, Management Science, vol.29, no.12, pp.1349-64.

Haho, P. (1992) 'Game experiences from Neles-Jamesbury' in: Ruohomäki, V., Vartiainen, M. (eds) Simulation games as educational tools in the learning organization (in Finnish). Helsinki University of Technology, Industrial Management and Industrial Psychology, Report 140, TKK OFFSET, Espoo, 1992, 45-49.

Haho, P. and Smeds, R. (1997) The Softmatch-method: Enterprise Transformation through Simulation Games, in The International Simulation and Gaming Yearbook, Volume 5, Research into Simulations in Education (ed. D. Saundes and B. Cox), London, Kogan Page.

Haho, P. (1998) Tailored simulation games for successful business process development. In: R.Smeds \& J.O.Riis: Experimental Learning in Production Management. Chapman\&Hall, UK, 1998, 24-39.

Laakso, T. (1997) Performance Evaluation and Process Interventions - A Method for Business Process Development. Acta Polytechnica Scandinavica, Matematics, Computing and Management in Engineering Series. No. 86, Espoo, Finnish Academy of Technology.

Mintzberg, H. (1994a) The Fall and Rise of Strategic Planning, Harvard Business Review, 1994, January-February, 107-114.

Moss Kanter, R. (1983) The Change Masters. Innovation and Entrepreneurship in the American Corporation. New York, Simon \& Schuster, Inc.

Nonaka, I. and Takeuchi H. (1995) The Knowledge-Creating Company, How Japanese Companies Create the Dynamics of Innovation. Oxford, Oxford University Press.

Smeds, R. (1997) Radical change through incremental innovations: generic principles and cultural differences in evolution management, Int. J. Technology Management, vol. 14, no. 1, pp. 146-162.

Smeds, R. (1996) Successful transformation: strategic evolution management for competitive advantage, Business Change and Reengineering. The Journal of Corporate Transformation, vol. 2, no. 3, pp. 62-72.

Smeds, R. and Haho, P. (1995a) Tailored order-to-delivery process game, in Simulation games and Learning in Production Management (ed. J. Riis), London, Chapman \&Hall, 145-155.

van de Ven, A. H. (1986) Central problems in the management of innovation, Management Science, vol.32, no.5, pp. 590-607.

Östel, H. (1996) Learning Processes in Inter-Organizational Partnerships in: The Second European Academies of Management Conference on "European Management Issues", Brussesls, IFSAM. 